\title{
The impact of the rise in atmospheric nitrous oxide on stratospheric ozone
}

\author{
This article belongs to Ambio's 50th Anniversary Collection. Theme: Ozone Layer
}

\author{
Rolf Müller
}

Published online: 21 November 2020

More than forty years ago Ambio published a paper that raised concerns about the increased use of fixed nitrogen as fertiliser in that the resulting increase in nitrous oxide $\left(\mathrm{N}_{2} \mathrm{O}\right)$ emissions to the atmosphere could result in a significant reduction of the Earth's ozone shield (Crutzen and Ehhalt 1977). It presented another case of human activities at the Earth's surface impacting on the stratospheric ozone layer. Today, it is known that atmospheric $\mathrm{N}_{2} \mathrm{O}$, which is present in the atmosphere in 2020 at a mixing ratio of 332.8 $\mathrm{ppb}^{1}$, is not only important for stratospheric ozone but also constitutes the third most important long-lived greenhouse gas (after $\mathrm{CO}_{2}$ and $\mathrm{CH}_{4}$ ).

$\mathrm{N}_{2} \mathrm{O}$ is essentially inert in the troposphere and has no significant sinks at the surface of the Earth. However, when transported to the stratosphere it will be broken down mainly via photolysis at short wavelengths (below $200 \mathrm{~nm}$ )

$\mathrm{N}_{2} \mathrm{O}+\mathrm{h} v \rightarrow \mathrm{N}_{2}+\mathrm{O}\left({ }^{1} \mathrm{D}\right) .(\mathrm{R} 1)$

To a lesser extent, $\mathrm{N}_{2} \mathrm{O}$ is also broken down by reaction with $\mathrm{O}\left({ }^{1} \mathrm{D}\right)$

$\mathrm{N}_{2} \mathrm{O}+\mathrm{O}\left({ }^{1} \mathrm{D}\right) \rightarrow \mathrm{N}_{2}+\mathrm{O}_{2}(\mathrm{R} 2)$

and

$\mathrm{N}_{2} \mathrm{O}+\mathrm{O}\left({ }^{1} \mathrm{D}\right) \rightarrow 2 \mathrm{NO}(\mathrm{R} 3)$

where the primary source of $\mathrm{O}\left({ }^{1} \mathrm{D}\right)$ in the atmosphere is the photolysis of ozone (at wavelengths below $320 \mathrm{~nm}$ ). Reaction R3 constitutes the major source of nitrogen oxides in the stratosphere, but less than $10 \%$ of the atmospheric $\mathrm{N}_{2} \mathrm{O}$ is converted to nitrogen oxides (e.g. Ravishankara et al. 2009; Portmann et al. 2012; Fleming et al. 2015).

The breakdown in the stratosphere determines the atmospheric lifetime of $\mathrm{N}_{2} \mathrm{O}$; the SPARC (Stratosphere- troposphere Processes And their Role in Climate) lifetime assessment estimated the $\mathrm{N}_{2} \mathrm{O}$ lifetime to be 123 years (with a 2- $\sigma$ range of 104-152 years; SPARC 2013), while more recently Prather et al. (2015) recommend a slightly shorter lifetime of $116 \pm 9$ years, which is however consistent with the SPARC value within uncertainties.

In the stratosphere, nitrogen oxides $\left(\mathrm{NO}\right.$ and $\left.\mathrm{NO}_{2}\right)$ destroy ozone through the following catalytic cycle (Crutzen 1970; Johnston 1971)

$$
\begin{array}{r}
\mathrm{NO}+\mathrm{O}_{3} \rightarrow \mathrm{NO}_{2}+\mathrm{O}_{2}(\mathrm{R} 4) \\
\mathrm{NO}_{2}+\mathrm{O} \rightarrow \mathrm{NO}+\mathrm{O}_{2}(\mathrm{R} 5) \\
\ldots \\
\text { net } \mathrm{O}_{3}+\mathrm{O} \rightarrow 2 \mathrm{O}_{2}(\mathrm{C} 1)
\end{array}
$$

Cycle $\mathrm{C} 1$ constitutes the dominant catalytic ozone loss cycle in the extrapolar regions (Fig. 1). This cycle is essential for quantifying the stratospheric ozone budget and, consequently, the total column of ozone (e.g. Crutzen et al. 1995; Grooß et al. 1999). At altitudes below $20 \mathrm{~km}$ and above $45 \mathrm{~km}$, ozone loss driven by the $\mathrm{HO}_{\mathrm{x}}$ catalytic cycle dominates ozone loss rates (Fig. 1; Crutzen et al. 1995; Grooß et al. 1999; Müller 2009; Portmann et al. 2012).

The paper by Crutzen and Ehhalt (1977) was based on the discussions in the Nobel symposium No. 38, "Nitrogen - An essential life factor and a growing environmental hazard" in 1976, the proceedings of which were published as well in Ambio (Bolin and Arrhenius 1977). At that time, many aspects of atmospheric $\mathrm{N}_{2} \mathrm{O}$ were not known and the knowledge of the budget and of sources and sinks of atmospheric $\mathrm{N}_{2} \mathrm{O}$ was very incomplete (e.g. Bolin and

\footnotetext{
${ }^{1}$ In May 2020, based on the NOAA data web page, see caption of Fig. 2.
} 

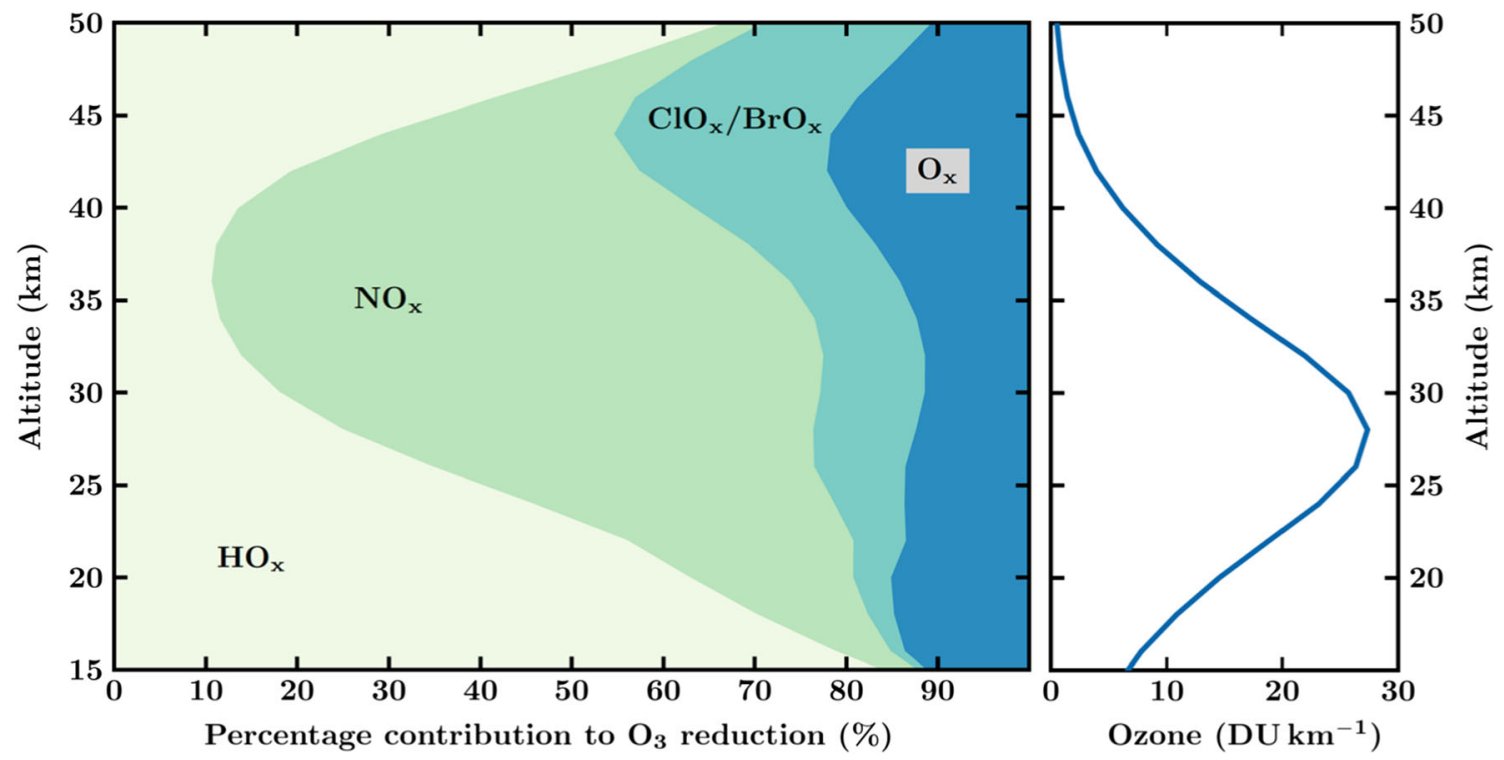

Fig. 1 Relative chemical efficiency of catalytic cycles destroying ozone in the stratosphere and the vertical distribution of the ozone concentration (similar to Fig. 2 in Crutzen and Ehhalt, 1977). Data are from a model simulation of the NOCAR model (Portmann et al., 2012) for near global conditions $\left(60^{\circ} \mathrm{S}-60^{\circ} \mathrm{N}\right)$ and for levels of source gases for the year 2000. Left hand panel shows the ozone loss rates by chemical family; $\mathrm{NO}_{\mathrm{x}}$ denotes the catalytic cycle driven by nitrogen oxides $(\mathrm{C} 1) ; \mathrm{HO}_{\mathrm{x}}$ and $\mathrm{ClO}_{\mathrm{x} /} \mathrm{BrO}_{\mathrm{x}}$ the similar catalytic cycles driven by $\mathrm{HO}_{\mathrm{x}}$ and $\mathrm{ClO}_{\mathrm{x}} / \mathrm{BrO}_{\mathrm{x}}$ cycles (see Portmann et al., 2012; WMO 2018), while $\mathrm{O}_{\mathrm{x}}$ denotes the Chapman (1930) cycle. Right hand panel shows the mean $\left(60^{\circ} \mathrm{S}-60^{\circ} \mathrm{N}\right)$ profile of ozone concentrations in units of Dobson units (DU) per kilometre. The Dobson unit is a measure of total column ozone (1 $\mathrm{DU}=2.69 \times 10^{16}$ molecules $\left.\mathrm{cm}^{-2}\right)$ and DU km${ }^{-1}$ is a measure of ozone concentration $\left(1 \mathrm{DU} \mathrm{km}{ }^{-1}=2.69 \times 10^{11}\right.$ molecules $\left.\mathrm{cm}^{-3}\right)(\mathrm{Data}$ shown here are courtesy of R. Portmann.)

Arrhenius 1977; Crutzen and Ehhalt 1977). Some of the $\mathrm{N}_{2} \mathrm{O}$ formation rates proposed in the literature required sources of fixed nitrogen far larger than known. Crutzen and Ehhalt (1977) stated that some "observations showing large spatial and temporal variations of nitrous oxide concentrations in the atmosphere favour the view that there are large sources of nitrous oxide, possibly exceeding 100 $\mathrm{Tg}(\mathrm{N}) /$ year"; the current estimate for global annual emissions is between 16.1 and $18.7 \mathrm{TgN} /$ year or about 17 $\mathrm{TgN} / \mathrm{year}$ over the last decade (Thompson et al. 2014, 2019; WMO 2018).

Further, the role of the ocean was unclear, it was stated that "a smaller source or even a sink of $\mathrm{N}_{2} \mathrm{O}$ [at the ocean surface] during larger concentrations of $\mathrm{N}_{2} \mathrm{O}$ should be considered" (Crutzen and Ehhalt 1977). Today, it is established that the oceans are an important natural source of atmospheric $\mathrm{N}_{2} \mathrm{O}$, with global emissions of about 3.5 $\mathrm{TgN} /$ year. In addition to natural emissions, there are currently also anthropogenic emissions of $\mathrm{N}_{2} \mathrm{O}$ from the ocean; the anthropogenic source of $\mathrm{N}_{2} \mathrm{O}$ from the ocean has increased from zero in 1950 to about $1 \mathrm{TgN} /$ year in 2000 (Syakila and Kroeze 2011).

In 1977, there were very few measurements of atmospheric $\mathrm{N}_{2} \mathrm{O}$ with rather large uncertainty ranges; therefore, the global distribution of atmospheric $\mathrm{N}_{2} \mathrm{O}$ and its variability were highly uncertain. In particular, there was only very limited information on the temporal development of
$\mathrm{N}_{2} \mathrm{O}$. A first step forward were measurements of $\mathrm{N}_{2} \mathrm{O}$ between 1976 and 1980 at monitoring stations and aboard research vessels; these measurements showed an annual increase of $\mathrm{N}_{2} \mathrm{O}$ of $\sim 0.2 \%$ per year and a mean global abundance of $\mathrm{N}_{2} \mathrm{O}$ (in 1978) of $299.8 \mathrm{ppb}$ (Weiss 1981). The temporal development and the global average mixing ratio of $\mathrm{N}_{2} \mathrm{O}$ were confirmed and extended later by further measurements (e.g. Prinn et al. 1983, 1990).

Determining the absolute calibration for atmospheric measurements of $\mathrm{N}_{2} \mathrm{O}$ accurately is demanding; however consistent atmospheric measurements of the temporal development of $\mathrm{N}_{2} \mathrm{O}$ from independent monitoring networks are available today (Dlugokencky et al. 1994; Saikawa et al. 2014; Prinn et al. 2018; WMO 2018; Dlugokencky et al. 2020; Lan et al. 2020) (Fig. 2). In recent years, $\mathrm{N}_{2} \mathrm{O}$ has been growing relatively steadily, at a rate of about 0.8-1.0 ppb/year (WMO 2018; Lan et al. 2020; see also light blue line in Fig. 2). The historical development of concentrations of $\mathrm{N}_{2} \mathrm{O}$ in the atmosphere is known from measurements in firn and ice cores (Fig. 2, blue line). Measurements in firn provide information on the more recent history (the past $\sim 65$ years) and measurements in ice cores are going back 2000 years with a reasonable time resolution (Fig. 2), but can provide information up to 800000 years back in history (MacFarling Meure et al. 2006; Rubino et al. 2019). 


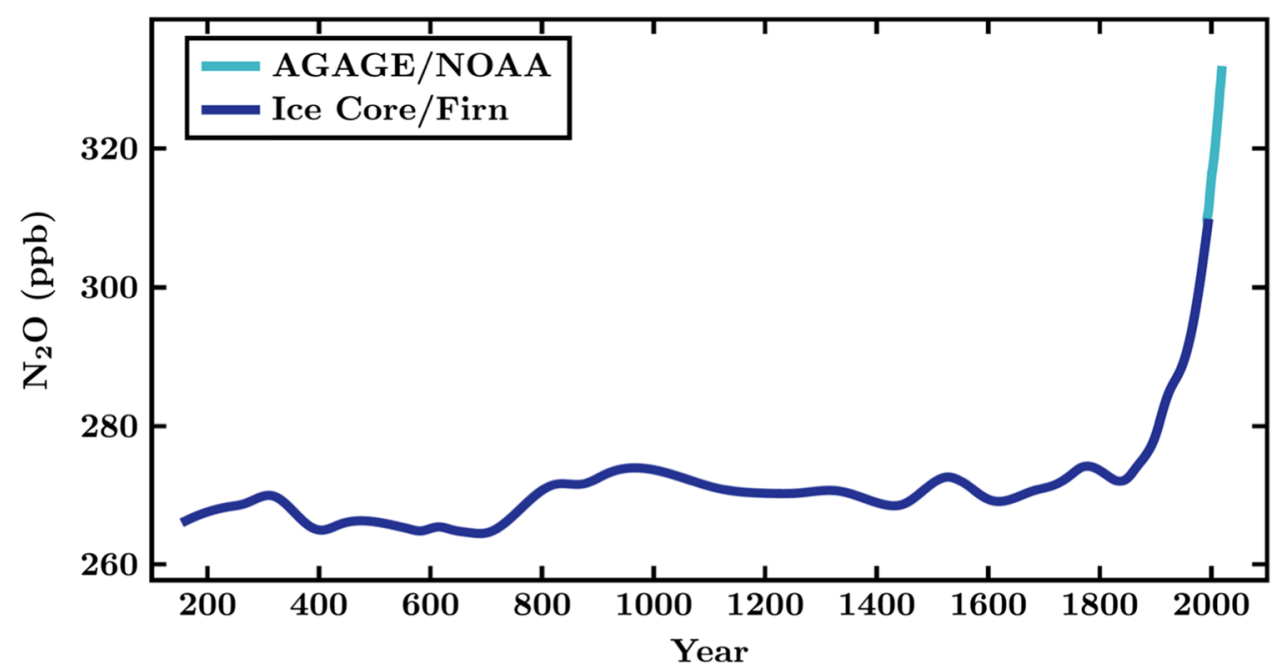

Fig. 2 Temporal development of atmospheric concentrations of $\mathrm{N}_{2} \mathrm{O}$ over the past $\sim 2000$ years. Historical data are deduced from the Law Dome ice core, more recent data (for the past $\sim 65$ years) are deduced from firn air (blue line, MacFarling Meure, et al. 2006; Rubino et al., 2019). The most recent data (after 1995, light blue line) are global mean data from the atmospheric monitoring networks AGAGE (Prinn et al., 2018) and NOAA (Dlugokencky et al., 2020). The recent AGAGE and NOAA records agree so well that they are not distinguished in this figure. Both the AGAGE and the NOAA record continues to today. (The spline fit applied to the ice core and firn data attenuates variations with periods of less than 100 years (MacFarling Meure, et al. 2006; Rubino et al., 2019).) Note that the industrial production of fixed nitrogen (Haber-Bosch process) started in 1913. Data sources: Law Dome Ice Core data for $\mathrm{N}_{2} \mathrm{O}$ (https://data.csiro.au/collections/collection/CIcsiro:37077v1) and data on the recent $\mathrm{N}_{2} \mathrm{O}$ atmospheric mixing ratios from station networks (NOAA/GML: www.esrl.noaa.gov/gmd/ccgg/trends_n2o/ and AGAGE : https://agage.mit.edu/data/agage-data)

In view of the many uncertainties present in 1977, the statements of Crutzen and Ehhalt (1977) were remarkably far sighted. Their paper made a strong point that "increased use of fixed nitrogen as fertilizer might result in a reduction of the Earth's ozone shield". A quantification of the fraction of ozone loss caused by anthropogenic $\mathrm{N}_{2} \mathrm{O}$ emissions was however prevented by these uncertainties in 1977. In fact, this environmental problem has been addressed by numerous authors since and is still an area of active research (e.g. Ravishankara et al. 2009; Portmann et al. 2012; Fleming et al. 2015; Butler et al. 2016).

Further, Crutzen and Ehhalt (1977) stated that it "seems possible that present agricultural and waste treatment practices will lead gradually to more $\mathrm{N}_{2} \mathrm{O}$ in the atmosphere by denitrification of the increasing amounts of fixed nitrogen being put in circulation by intensive agricultural methods". Today it is established that agricultural practices and the use of nitrogen fertilisers have greatly enhanced emissions of $\mathrm{N}_{2} \mathrm{O}$ to the atmosphere (with agricultural emissions amounting to 3.9-5.3 TgN/year in 2010; Syakila and Kroeze 2011; Thompson et al. 2019).

Finally, an important statement by Crutzen and Ehhalt (1977) was that "agricultural use of industrially (or maybe biologically) fixed nitrogen is by no means the only way in which man is interfering with the Earth's nitrogen cycle. It is for example likely that global $\mathrm{N}$-fixation rates were substantially smaller prior to man's agricultural transition". This statement in 1977 was made without the knowledge of the temporal development of $\mathrm{N}_{2} \mathrm{O}$ in the atmosphere (Fig. 2). Today it is known that $\mathrm{N}_{2} \mathrm{O}$ emissions have increased substantially from 10 to $12 \mathrm{TgN} /$ year before the industrial era to $\sim 17 \mathrm{TgN} /$ year in the last decade. Agricultural emissions caused the majority of this increase (emissions of $0.3-1.0 \mathrm{TgN} /$ year in 1850 and $3.9-5.3 \mathrm{TgN} /$ year in 2010), but there is also formation of $\mathrm{N}_{2} \mathrm{O}$ during combustion and industrial processes (Syakila and Kroeze 2011; Thompson et al. 2019).

In the future, because of the success of the Montreal Protocol and its amendments and adjustments in reducing ozone depleting halogen compounds in the atmosphere (WMO 2018), stratospheric ozone in the latter half of the $21^{\text {st }}$ century will be controlled by the temporal development of $\mathrm{CO}_{2}, \mathrm{CH}_{4}$, and $\mathrm{N}_{2} \mathrm{O}$ (Portmann et al. 2012; Butler et al. 2016). Because of the expected increase in atmospheric $\mathrm{N}_{2} \mathrm{O}$, the $\mathrm{NO}_{\mathrm{x}}$ driven ozone loss cycle $(\mathrm{C} 1)$ is expected to be the dominant, anthropogenically driven ozone loss cycle in the foreseeable future (Ravishankara et al. 2009; Portmann et al. 2012). However, because of the considerable uncertainties in emission estimates for $\mathrm{N}_{2} \mathrm{O}$, an accurate quantification of the anthropogenically caused ozone loss through the $\mathrm{NO}_{\mathrm{x}}$ cycle $(\mathrm{C} 1)$ is still challenging (Ravishankara et al. 2009).

Most plants cannot use molecular nitrogen $\left(\mathrm{N}_{2}\right)$. Thus, although $\mathrm{N}_{2}$ is by far the most abundant form of nitrogen in the Earth's atmosphere, the conversion or "fixation" of $\mathrm{N}_{2}$ into biologically available compounds is a process 
fundamental to the maintenance of life on Earth (e.g. Bolin and Arrhenius 1977). Emissions of $\mathrm{N}_{2} \mathrm{O}$ depend on the specifics of the nitrogen fixation processes. An accurate quantification of sectoral emissions of $\mathrm{N}_{2} \mathrm{O}$ (e.g. from agricultural practices, waste management and industrial sources) remains a challenge in the future. The best-known example of industrial nitrogen fixation, the Haber-Bosch process (a method of directly synthesising ammonia from molecular hydrogen and molecular nitrogen) was implemented on industrial scale in 1913. Only the establishment of the Haber-Bosch process made the large-scale, industrial production of synthetic fertiliser possible and in this way likely allowed the rise in the world's population (e.g. Bodirski et al. 2014). The development of abatement strategies for a reduction of anthropogenic emissions of $\mathrm{N}_{2} \mathrm{O}$ remains therefore a necessary, but not a simple task (Bodirski et al. 2014).

The paper by Crutzen and Ehhalt (1977) ends expressing the hope that it will be possible in the future to "lessen the stress exerted on the Earth's nitrogen cycle by man's enormous industrial and agricultural expansion". Earlier in their paper, the authors also stated that the application of large quantities of fixed nitrogen to agricultural soils will be necessary "to feed adequately the expected world population by the year 2010, at which time we may hope for a halt in further population growth". Unfortunately, the latter hope has not yet materialised and the anthropogenic stress on the Earth's nitrogen cycle continues to be a serious issue.

Acknowledgements The author thanks D. H. Ehhalt very much for his help in writing this paper; his advice on a variety of different aspects of this paper was invaluable. He also thanks E. Dlugokencky, J.-U. Grooß, R. Portmann, R. Prinn, A. R. Ravishankara, S. Tilmes and R. Weiss for comments on the paper. R. Portmann also provided the ozone loss rates and the profile of ozone concentrations based on the NOCAR model shown in Fig. 1. Data shown in Fig. 2 are courtesy of E. Dlugokencky, D.M. Etheridge, R. Prinn, M. Rubino, R. Wang, and R. Weiss.

Funding Open Access funding enabled and organized by Projekt DEAL.

Open Access This article is licensed under a Creative Commons Attribution 4.0 International License, which permits use, sharing, adaptation, distribution and reproduction in any medium or format, as long as you give appropriate credit to the original author(s) and the source, provide a link to the Creative Commons licence, and indicate if changes were made. The images or other third party material in this article are included in the article's Creative Commons licence, unless indicated otherwise in a credit line to the material. If material is not included in the article's Creative Commons licence and your intended use is not permitted by statutory regulation or exceeds the permitted use, you will need to obtain permission directly from the copyright holder. To view a copy of this licence, visit http://creativecommons. org/licenses/by/4.0/.

\section{REFERENCES}

Bodirsky, B., A. Popp, H. Lotze-Campen, J.P. Dietrich, S. Rolinski, I. Weindl, C. Schmitz, C. Müller, et al. 2014. Reactive nitrogen requirements to feed the world in 2050 and potential to mitigate nitrogen pollution. Nature Communications 5: 3858. https://doi. org/10.1038/ncomms4858.

Bolin, B., and E. Arrhenius. 1977. Nitrogen - An essential life factor and a growing environmental hazard. Ambio 6 (2-3): 96-105.

Butler, A.H., J.S. Daniel, R.W. Portmann, A.R. Ravishankara, P.J. Young, D.W. Fahey, and K.H. Rosenlof. 2016. Diverse policy implications for future ozone and surface UV in a changing climate. Environmental Research Letters 11: 064017.

Chapman, S. 1930. A theory of upper atmospheric ozone. Memoirs of the Royal Meteorological Society 3: 103-109.

Crutzen, P.J. 1970. The influence of nitrogen oxide on the atmospheric ozone content. Quarterly Journal of the Royal Meteorological Society 96: 320-325. https://doi.org/10.1002/qj. 49709640815.

Crutzen, P.J., and D.H. Ehhalt. 1977. Effects of nitrogen fertilizers and combustion on the stratospheric ozone layer. Ambio 6 (2-3): $112-117$.

Crutzen, P.J., J.-U. Grooß, C. Brühl, R. Müller, and J.M. Russell III. 1995. A reevaluation of the ozone budget with HALOE UARS data: No evidence for the ozone deficit. Science 268: 705-708.

Dlugokencky, E.J., L.P. Steele, P.M. Lang, and K.A. Masarie. 1994. The growth rate and distribution of atmospheric methane. Journal of Geophysical Research 99: 1702-17043. https://doi. org/10.1029/94JD01245.

Dlugokencky, E.J., A.M. Crotwell, J.W. Mund, M.J. Crotwell, and K.W. Thoning. 2020. Atmospheric Nitrous Oxide Dry Air Mole Fractions from the NOAA GML Carbon Cycle Cooperative Global Air Sampling Network, 1997-2019. Version: 2020-07. https://doi.org/10.15138/53g1-x417

Fleming, E.L., C. George, D.E. Heard, C.H. Jackman, M.J. Kurylo, W. Mellouki, V.L. Orkin, W.H. Swartz, et al. 2015. The impact of current $\mathrm{CH}_{4}$ and $\mathrm{N}_{2} \mathrm{O}$ atmospheric loss process uncertainties on calculated ozone abundances and trends. Journal of Geophysical Research: Atmospheres 120: 5267-5293. https://doi. org/10.1002/2014JD022067.

Grooß, J., R. Müller, G. Becker, D.S. McKenna, and P.J. Crutzen. 1999. The upper stratospheric ozone budget: An update of calculations based on HALOE data. Journal of Atmospheric Chemistry 34: 171-183. https://doi.org/10.1023/A: 1006290927549.

Johnston, H. 1971. Reduction of stratospheric ozone by nitrogen oxide catalysts from supersonic transport exhaust. Science 173 (3996): 517-522. https://doi.org/10.1126/science.173.3996.517.

Lan, X., B.D. Hall, G. Dutton, J. Mühle, and J.W. Elkins. 2020. Longlived greenhouse gases, [in "State of the Climate in 2019"]. Bulletin of the American Meteorological Society 101 (8): S70 S74. https://doi.org/10.1175/BAMS-D-20-0104.1.

MacFarling Meure, C., D. Etheridge, C. Trudinger, P. Steele, R. Langenfelds, T. van Ommen, A. Smith, and J. Elkins. 2006. The Law Dome $\mathrm{CO}_{2}, \mathrm{CH}_{4}$ and $\mathrm{N}_{2} \mathrm{O}$ ice core records extended to 2000 years BP. Geophysical Research Letters 33 (14): L14810. https:// doi.org/10.1029/2006GL026152.

Müller, R. 2009. A brief history of stratospheric ozone research. Meteorologische Zeitschrift 18 (1): 3-24.

Portmann, R.W., J.S. Daniel, and A.R. Ravishankara. 2012. Stratospheric ozone depletion due to nitrous oxide: influences of other gases. Philosophical Transactions of the Royal Society London B Biological Sciences 367 (1593): 1256-1264. https://doi.org/10. 1098/rstb.2011.0377. 
Prather, M.J., J. Hsu, N.M. DeLuca, C.H. Jackman, L.D. Oman, A.R. Douglass, E.L. Fleming, S.E. Strahan, et al. 2015. Measuring and modeling the lifetime of nitrous oxide including its variability. Journal of Geophysical Research: Atmospheres 120 (11): 5693-5705. https://doi.org/10.1002/2015JD023267.

Prinn, R.G., P. Simmonds, R. Rasmussen, R.D. Rosen, F.N. Alyea, C.A. Cardelino, A.J. Crawford, D.M. Cunnold, et al. 1983. The atmospheric lifetime experiment 1 . Introduction, instrumentation, and overview. Journal of Geophysical Research 88(C13): 8353-8367.

Prinn, R.G., D. Cunnold, R. Rasmussen, P. Simmonds, F. Alyea, A. Crawford, P. Fraser, and R. Rosen. 1990. Atmospheric emissions and trends of nitrous oxide deduced from 10 years of ALEGAGE data. Journal of Geophysical Research 95 (D11): 18369-18385.

Prinn, R.G., R.F. Weiss, J. Arduini, T. Arnold, H.L. DeWitt, P.J. Fraser, A.L. Ganesan, J. Gasore, et al. 2018. History of chemically and radiatively important atmospheric gases from the Advanced Global Atmospheric Gases Experiment (AGAGE). Earth System Science Data 10: 985-1018. https://doi.org/10. 5194/essd-10-985-2018.

Ravishankara, A.R., J.S. Daniel, and R.W. Portmann. 2009. Nitrous oxide $\left(\mathrm{N}_{2} \mathrm{O}\right)$ : The dominant ozone-depleting substance emitted in the 21 st century. Science 326 (5949): 123-125. https://doi.org/ 10.1126/science. 1176985

Rubino, M., D.M. Etheridge, D.P. Thornton, R. Howden, C.E. Allison, R.J. Francey, R.L. Langenfelds, L.P. Steele, et al. 2019. Revised records of atmospheric trace gases $\mathrm{CO}_{2}, \mathrm{CH}_{4}, \mathrm{~N}_{2} \mathrm{O}$, and $\delta^{13} \mathrm{C}_{-} \mathrm{CO}_{2}$ over the last 2000 years from Law Dome, Antarctica. Earth System Science Data 11: 473-492. https://doi.org/10.5194/ essd-11-473-2019.

Saikawa, E., R.G. Prinn, E. Dlugokencky, K. Ishijima, G.S. Dutton, B.D. Hall, R. Langenfelds, Y. Tohjima, et al. 2014. Global and regional emissions estimates for $\mathrm{N}_{2} \mathrm{O}$. Atmospheric Chemistry and Physics 14: 4617-4641. https://doi.org/10.5194/acp-144617-2014.

Schilt, A., E.J. Brook, T.K. Bauska, D. Baggenstos, H. Fischer, F. Joos, V.V. Petrenko, H. Schaefer, et al. 2014. Isotopic constraints on marine and terrestrial $\mathrm{N}_{2} \mathrm{O}$ emissions during the last deglaciation. Nature 516: 234-237. https://doi.org/10.1038/ nature 13971.

SPARC (Stratosphere-troposphere Processes And their Role in Climate). 2013. SPARC Report on the Lifetimes of Stratospheric Ozone-Depleting Substances, Their Replacements, and Related Species, edited by M. Ko, P. Newman, S. Reimann, and S. Strahan, SPARC Report No. 6, WCRP-15/2013.

Syakila, A., and C. Kroeze. 2011. The global nitrous oxide budget revisited. Greenhouse Gas Measurement and Management 1: 17-26. https://doi.org/10.3763/ghgmm.2010.0007.

Thompson, R.L., K. Ishijima, E. Saikawa, M. Corazza, U. Karstens, P.K. Patra, P. Bergamaschi, F. Chevallier, et al. 2014. TransCom $\mathrm{N}_{2} \mathrm{O}$ model inter-comparison. Part 2: Atmospheric inversion estimates of $\mathrm{N}_{2} \mathrm{O}$ emissions. Atmospheric Chemistry and Physics 14 (12): 6177-6194. https://doi.org/10.5194/acp-14-6177-2014.

Thompson, R.L., L. Lassaletta, P.K. Patra, K.C. Wilson, A. Gressent, E.N. Koffi, M.P. Chipperfield, W. Winiwarter, et al. 2019. Acceleration of global $\mathrm{N}_{2} \mathrm{O}$ emissions seen from two decades of atmospheric inversion. Nature Climate Change 9: 993-998. https://doi.org/10.1038/s41558-019-0613-7.

Weiss, R. 1981. The temporal and spatial distribution of tropospheric nitrous oxide. Journal of Geophysical Research 86 (C8): $7185-7195$.

WMO (World Meteorological Organization). 2018. Scientific assessment of ozone depletion: 2018, Global Ozone Research and Monitoring Project-Report No. 58, 588 pp., Geneva, Switzerland.

Publisher's Note Springer Nature remains neutral with regard to jurisdictional claims in published maps and institutional affiliations.

\section{Rolf Müller ( $\square)$}

Address: Forschungszentrum Jülich $\mathrm{GmbH}$, Institut für Energie und Klimaforschung (IEK-7), 52425 Jülich, Germany.

e-mail: ro.mueller@fz-juelich.de 